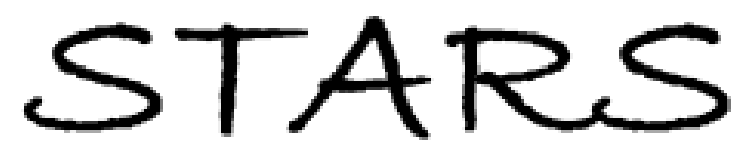

University of Central Florida

STARS

$1-1-2011$

\title{
Half-Dead Colonies of Montastraea Annularis Release Viable Gametes On A Degraded Reef In The Us Virgin Islands
}

Ilsa B. Kuffner

T. Don Hickey

Valerie J. Paul

Jennifer M. Morrison

Linda J. Walters

University of Central Florida

See next page for additional authors

Find similar works at: https://stars.library.ucf.edu/facultybib2010

University of Central Florida Libraries http://library.ucf.edu

This Editorial Material is brought to you for free and open access by the Faculty Bibliography at STARS. It has been accepted for inclusion in Faculty Bibliography 2010 s by an authorized administrator of STARS. For more information, please contact STARS@ucf.edu.

\section{Recommended Citation}

Kuffner, Ilsa B.; Hickey, T. Don; Paul, Valerie J.; Morrison, Jennifer M.; Walters, Linda J.; Grablow, Katie R.; Turner, Teresa; and Parish, Edward R., "Half-Dead Colonies of Montastraea Annularis Release Viable Gametes On A Degraded Reef In The Us Virgin Islands" (2011). Faculty Bibliography 2010s. 1510.

https://stars.library.ucf.edu/facultybib2010/1510

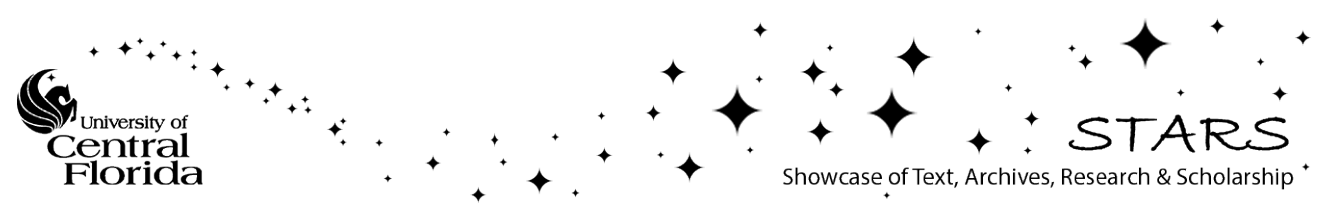




\section{Authors}

Ilsa B. Kuffner, T. Don Hickey, Valerie J. Paul, Jennifer M. Morrison, Linda J. Walters, Katie R. Grablow, Teresa Turner, and Edward R. Parish 


\title{
HALF-DEAD COLONIES OF MONTASTRAEA ANNULARIS RELEASE VIABLE GAMETES ON A DEGRADED REEF IN THE US VIRGIN ISLANDS
}

\author{
Ilsa B Kuffner, T Don Hickey, Valerie J Paul, Jennifer M Morrison, \\ Linda J Walters, Katie R Grablow, Teresa Turner, and Edward R Parish
}

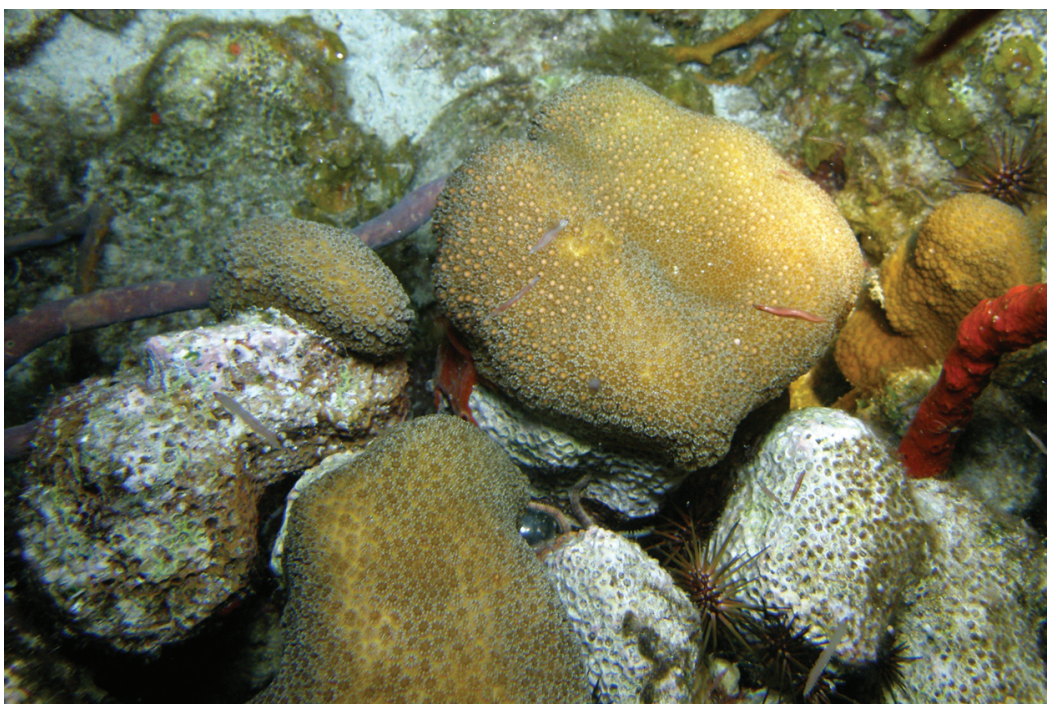

This figure shows a partially dead Montastraea annularis (Ellis and Solander, 1786) colony preparing to release gamete bundles on the night of 11 September, 2009, on Tektite Reef, St. John, US Virgin Islands (photo credit: K Grablow). In 2005, a protracted high-temperature anomaly resulted in significant coral bleaching followed by an outbreak of coral disease in the US Virgin Islands (Miller et al. 2009). The Tektite Reef population of Montastraea spp. (mainly $M$. annularis) experienced high mortality, due mainly to white plague (Miller et al. 2009). We monitored the September 2009 coral spawning at this reef in the 3.5-7 m depth range, observing $\sim 50$ colonies in a $30 \times 30 \mathrm{~m}$ area. Gamete release by M. annularis on the seventh night after the full moon was quite spectacular. On that night (11 September), we observed the first colony preparing to release gamete bundles ("setting") $3.13 \mathrm{hrs}$ after sunset (21:33 hrs AST). Gamete release began $\sim 15 \mathrm{~min}$ later, peaking after about $30 \mathrm{~min}$, and continuing for at least $45 \mathrm{~min}$. We estimate that $>90 \%$ of the population spawned on that night, and the colonies that spawned released gametes from $>95 \%$ of their live tissue area. Gametes from at least 20 colonies were collected with plankton nets suspended above each individual (defined as contiguous skeleton, regardless of contiguous live tissue) and combined, resulting in very high fertilization rates (near 100\%, determined with microscopic examination in the laboratory). The number of colonies participating in the spawning event was particularly impressive considering that many of these colonies exhibited $50 \%$ or greater partial mortality.

This finding has considerable management implications. Montastraea annularis is a major reef builder in the Caribbean, and it is noteworthy that even compromised colonies that have sustained partial to considerable mortality can still generate gametes and continue to contribute to the genetic diversity of a reef. Therefore, resource protection efforts that could result in the preservation of live corals (e.g., smallscale shading, watershed management) are worthwhile even if entire reefs cannot be saved. Tektite Reef is contained within the Virgin Islands National Park adjacent to an undeveloped watershed. Efforts to protect degraded reefs such as this from local-scale insult should continue, for here it is shown that they can still be reproductively viable. 


\section{Literature Cited}

Miller J, Muller E, Rogers C, Waara R, Atkinson A, Whelan K, Patterson M, Witcher B. 2009. Coral disease following massive bleaching in 2005 causes $60 \%$ decline in coral cover on reefs in the US Virgin Islands. Coral Reefs. 25:418. http://dx.doi.org/10.1007/s00338-006-0125-6

Date Submitted: 9 December, 2010.

DATE ACCEPTED: 28 February, 2011.

Available Online: 16 March, 2011.

Addresses: (IBK, TDH, JMM) US Geological Survey, 600 Fourth Street South, St. Petersburg, Florida 33701. (VJP) Smithsonian Marine Station at Fort Pierce, 701 Seaway Drive, Fort Pierce, Florida 34949. (LJW, KRG) University of Central Florida, Department of Biology, 4000 Central Florida Blvd., Orlando, Florida 32816. (TT, ERP) University of the Virgin Islands, Division of Science and Mathematics, St. Thomas, Virgin Islands 00802. CoRresPONDING AuthoR: (IK) E-mail:<ikuffner@usgs.gov>.

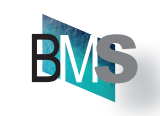

